\title{
Adaptasi Kebiasaan Baru Selama Pandemic melalui Upaya Peningkatan Produktifitas Wirausaha Mandiri Menuju Ekonomi Berkeadilan
}

\author{
Nafisah Yuliani ${ }^{1 *}$, Diah Pramestari ${ }^{2}$, dan Henni ${ }^{3}$
}

\author{
1,2,3 Universitas Persada Indonesia YAI \\ Email: ${ }^{1}$ nafisah.y@gmail.com ${ }^{2}$ mesta_dp@yahoo.com ${ }^{3}$ henn1_bm@yahoo.com
}

\begin{tabular}{ccc}
\hline Diterima & Direvisi & Disetujui \\
$08-09-2021$ & $18-09-2021$ & $20-09-2021$ \\
\hline
\end{tabular}

\begin{abstract}
Abstrak - Penelitian ini bertujuan untuk mengetahui upaya peningkatan produktifitas wirausaha mandiri menuju ekonomi berkeadilan sebagai bentuk adaptasi selama pandemic . Sampel terdiri dari para mahasiswa yang sudah punya usaha ataupun yang belum punya usaha sebanyak 137 mahasiswa. Data dikumpulkan melalui survei mail (google formulir) dan dianalisis dengan metode deskriptif untuk mengetahui gambaran dari responden terhadap masalah yang diteliti. Hasil penelitian ini menunjukkan upaya peningkatan produktifitas wirausaha melalui perbaikan karakteristik pengusaha yang unggul, perbaikan strategi pemasaran dan peningkatan performa bisnis merupakan bentuk adaptasi baru dimasa pandemi agar terwujud wirausaha mandiri menuju ekonomi berkeadilan. Hasil penelitian ini juga memiliki dua implementasi: (1) implementasi teoritis untuk hasil penelitian ini adalah agar terwujud wirausaha mandiri menuju ekonomi berkeadilan, maka penerapan strategi bersaing berupa Strategi Kepemimpinan Biaya (Cost Leadership Strategy), Strategi Diferensiasi (Differentiation Strategy), Strategi Inovasi (Innovation Strategy), Strategi Pertumbuhan (Growth Strategy), Strategi Aliansi (Alliance Strategy), (2) implementasi manajerial untuk hasil penelitian ini adalah adanya upaya peningkatan produktifitas wirausaha melalui perbaikan karakteristik pengusaha yang unggul perbaikan strategi pemasaran dan peningkatan performa bisnis merupakan bentuk adaptasi baru dimasa pandemi agar terwujud wirausaha mandiri menuju ekonomi berkeadilan. Hal ini memberikan motivasi untuk bertahan ditengah persaingan yang tinggi dengan penguasaaan TIK yang mumpuni dan melakukan ekspansi ke mancanegara.
\end{abstract}

Kata kunci: Adaptasi Kebiasaan Baru, Produktifitas, Wirausaha Mandiri

\begin{abstract}
This study aims to determine the efforts to increase the productivity of independent entrepreneurs towards a just economy as a form of adaptation during a pandemic. The sample consists of students who already have a business or who do not have a business as many as 137 students. The data was collected through a mail survey (google forms) and analyzed by descriptive method to find out the description of the respondents to the problem under study. The results of this study indicate that efforts to increase entrepreneurial productivity through improving the characteristics of superior entrepreneurs, improving marketing strategies and improving business performance are a new form of adaptation during the pandemic in order to realize independent entrepreneurship towards a just economy. The results of this study also have two implementations: (1) theoretical implementation for the results of this study is to realize independent entrepreneurship towards a just economy, then the application of competitive strategies in the form of Cost Leadership Strategy, Differentiation Strategy, Innovation Strategy ( Innovation Strategy), Growth Strategy, Alliance Strategy, (2) managerial implementation for the results of this study is an effort to increase entrepreneurial productivity through improving the characteristics of superior entrepreneurs, improving marketing strategies and improving business performance as a form of adaptation. only during the pandemic to realize independent entrepreneurship towards a just economy. This provides motivation to survive in the midst of high competition with good ICT mastery and expand overseas
\end{abstract}

Keywords: Adapting to New Habits, Productivity, Self-Employment

\section{PENDAHULUAN}

Telah lebih dari satu tahun pandemic Covid 19 terjadi. Dampak Pandemic dirasakan semua sector, khususnya pelaku UMKM, berdasarkan laporan Survei Berdasarkan data ADBSI 2020 dalam (Jayani, 2020),dampak pandemic berupa penurunan permintaan dan dan turunnya pejualan, penurunan kegitan, kesulitan sampai dengan penutupan usaha (sementara/tetap), kesulitas cash-flow dan kredit bermasaah/macet pada lembaga keuangan, distribusi terhambat, kesulitan bahan baku dan kesulitan mendapatkan permodalan usaha. 
Dampak Covid 19 terhadap dunia usaha disajikan pada gambar 1 .

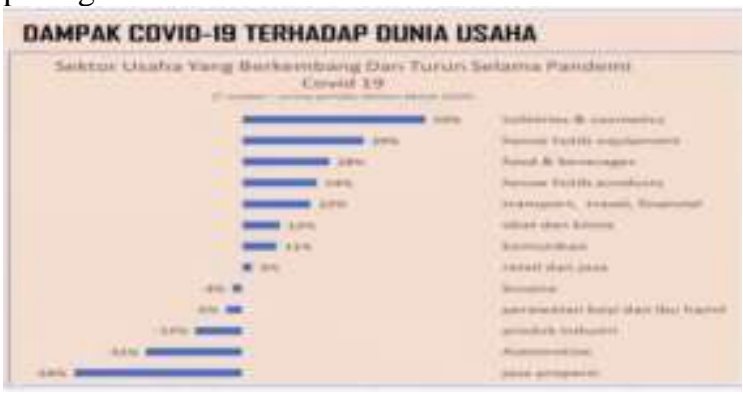

Gambar 1. Dampak Covid 19 Terhadap Dunia Usaha ( Sumber : (Bayu, 2020)

Pada gambar 1 terlihat bahwa dampak Covid-19 terhadap dunia usaha, terjadi penurunan paling besar pada jasa properti sebanyak 54\%, automotif $31 \%$, produk industri $15 \%$. Peningkatan paling besar untuk sektor usaha toiletries dan cosmetics sebesar 59\%, house holds equipment $39 \%$ dan food \& beverage $28 \%$.

Revolusi Industri 4.0 merupakan upaya adaptasi baru yang ditandai penggantian tenaga manusia dengan mesin yang dilakukan secara otomatis. Sehubungan hal tersebut, kebutuhan Sumber Daya Manusia (SDM) dalam bidang Teknologi Informasi dan Komunikasi (TIK) menjadi sangat penting dan mendesak untuk dilakukan perbaikan. Perbaikan kualitas dan kuantitas SDM akan menjadi faktor penentu agar SDM dapat bertahan di era teknologi. Di samping itu, pandemic telah mengubah paradigma dalam berwirausaha. Wirausaha saat ini dituntut untuk melek teknologi untuk menunjang proses penjualannya yang mulai bergeser dari system offline ke system online. Dengan adanya system penjualan online, maka wirausah dituntut mahir menggunakan teknologi untuk memperluas pasar, memudahkan promosi dan update produk terbaru agar tidak tertinggal dengan pesaingnya. Oleh karena itu, diperlukan peningkatan produktifitas dari wirausaha tersebut. Dengan adanya upaya peningkatan produktifitas wirausaha maka akan terwujud wirausaha mandiri menuju ekonomi berkeadilan sebagai bentuk adaptasi baru selama pandemic.

\section{Produktivitas}

Produktifitas adalah proses mengubah sumber daya menjadi barang dan jasa yang bisa dimanfaatkan oleh masyarakat. Menurut (Heizer, Jay dan Render, 2015) peningkatan produktivitas berarti perbandingan yang naik antara jumlah sumber daya yang dipakai (input) dengan jumlah barang dan jasa yang dihasilkan. Pengukuran produktifitas ini bermanfaat untuk evaluasi kemampuan suatu negara meyediakan standar hidup yang baik bagi penduduknya. Dengan penambahan produktivitas, maka standar kehidupan dapat membaik. Terjadi hubungan yang berbanding terbalik antara peningkatan produktifitas dan harga. Harga akan naik, jika tenaga kerja, modal, manajemen ditingkatkan tanpa meningkatnya produktivitasnya dan sebalinya.

Untuk meningkatkan produktifitas diperlukan inovasi yang update dan terus dilakukan. Jika produktifitas meningkat maka hal ini akan mendukung proses operasi secara keseluruhan.

Sehubungan upaya peningkatan produktivitas UMKM, wirausaha mandiri dituntut untuk melek teknologi untuk menunjang proses penjualannya yang mulai bergeser dari system offline ke system online. Dengan adanya system penjualan online, maka wirausah dituntut mahir menggunakan teknologi untuk memperluas pasar, memudahkan promosi dan update produk terbaru agar tidak tertinggal dengan pesaingnya. Untuk itu diperlukan peningkatan produktifitas dari wirausaha tersebut.berdasarkan laporan penelitan Puslitbang Aptika-IKP tahun 2019, Jumlah kebutuhan SDM Bidang TIK Usaha Besar disajikan pada gambar 2.

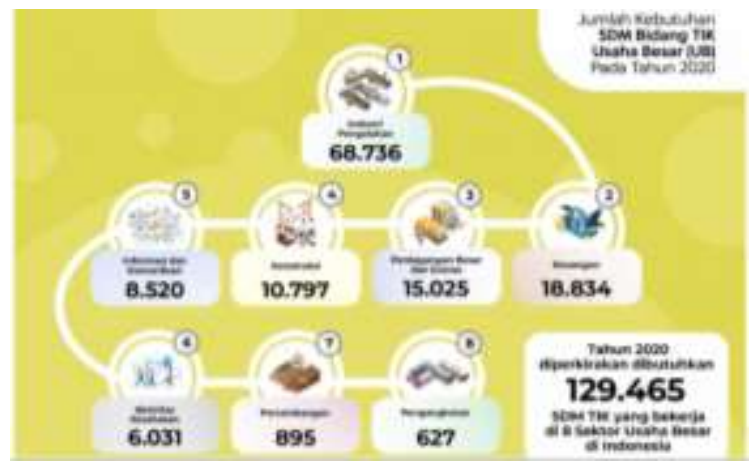

Gambar 2. Jumlah Kebutuhan SDM TIK Usaha besar Pada tahun 2020 (Sumber :(Agustina, 2019)

Berdasarkan gambar 2 ditas, maka di tahun 2020 diperkirakan dibutuhkan 129.465 SDM TIK yang bekerjs di 8 sektor usaha besar di Indonesia. Untuk mendukung kebutuhan SDM TIK tersebut, perlu upaya meningkatkan produktivitas SDM, khususnya wirausaha mandiri yang melek teknologi dan bersiap bersaing di dunia usaha. Upaya meningkatkan produktifitas SDM bisa dilakukan dengan cara menciptakan sesuatu yang baru dan berbeda (creatif new and different) melalui cara berpikir kreatif dan inovatif untuk menciptakan peluang (Suryana, 2014). Ada 3 faktor dalam meningkatkan produktifitas para wirausaha, yaitu Karakteristik pengusaha, strategi pemasaran dan performa bisnis. Ketiga faktor tersebut saling terhubung dan mempengaruhi antara faktor satu dengan faktor lainnya. Seorang wirausaha mandiri akan membuat strategi bisnis dengan cara berpikir kreatif dan inovatif. Hal ini akan berimbas dengan naiknya performa usaha mereka. Untuk itu dibutuhkan kemampuan, pengetahuan dan ketrampilan wirausaha mandiri.

\section{Karakteritik Pengusaha}

Proses operasi usaha akan dipengaruhi karakteristik wirausaha mandiri dalam menjalankan usahanya. 
Dua hal yang perlu dimiliki seorang wirausaha mandiri adalah entrepreneurial mentality dan administrative mentality. Entrepreneurial mentality adalah kemampuan mental seseorang wirausaha mandiri untuk bisa berinovasi menghasilkan produkproduk yang diinginkan konsumen, bisa memimpin team-work-nya dalam bekerja, bisa mengambil keputusan dalam memajukan usahanya, kemampuan melihat peluang usaha di masa yang akan datang, dan kemampuan problem solving. Seorang wirausaha mandiri dengan entrepreneurial mentality yang tinggi terlihat mandiri, individualistis, dan berpikir positif. Administrative mentality adalah kemampuan mental seorang wirausaha mandiri sebagai pribadi dalam analytical ability dan ability to the reality. Analytical ability mencakup kemampuan mental seseorang wirausaha mandiri untuk bisa untuk mengumpulkan informasi, berpikir sistematik, kalkulasi data, dan memecahkan masalah. Ability to the reality mencakup kemampuan mental seorang wirausaha mandiri untuk bisa untuk bekerja sama, berpikir rasional, konsisten, dan stabil.

Menurut (Suryana, 2014), karakateristik wirausaha mandiri mempunyai ciri-ciri : (1) percaya diri, (2) berorientasi pada tugas dan hasil, (3) berani menghadapi resiko, (4) berjiwa pemimpin, (5) keorisinalan, (6) berorientasi masa depan.

\section{Strategi Pemasaran}

Prinsip dasar pemasaran adalah menciptakan nilai bagi pelanggan (customer value), keunggulan bersaing (competitif advantage) dan fokus pemasaran (Suryana, 2014) Strategi pemasaran adalah upaya untuk memasarkan produk yang dihasilkannya agar menjangkau pangsa pasar yang lebih luas. Strategi pemasaran yang dibikin disesuaikan dengan target pasar yang diinginkan. Oleh karena itu diperlukan kreatifitas dalam merancang strategi pemasaran yang tepat sasaran Tujuan pemasaran adalah bisa mendistribusikan barang dan jasa yang telah diproduksi untuk memenuhi kebutuhan konsumen dan produk tersebut dibeli oleh konsumen (Supranto, 2019). Untuk memulai pemasaran, harus dimulai dengan adanya riset pemasaran yang bertujuan untuk meneliti produk apa saja yang dibutuhan dan diinginkan konsumen agar tercipta nilai tambah yang lebih tinggi bagi konsumen daripada nilai yang diciptakan pesaingnya.

\section{Performa Bisnis}

Performa bisnis adalah gambaran yang menunjukkan perkembangan suatu usaha, berkembang naik atau turun. Usaha dengan performa baik ditunjukkan oleh tingkat penjualan yang tinggi, keuntungan dan pengembalian modal yang tinggi, turnover karyawan yang rendah, dan meluasnya pangsa pasar. Untuk memperoleh performa bisnis yang baik, perlu manajemen yang baik terutama manajemen keuangan usaha atau bisnis yang dijalani. Berbagai bentuk skala usahanya, manajemen keuangan itu penting.

Menurut (Suryana, 2014), dalam memulai usaha dibutuhkan perencanaan usaha yang memuat unsurunsur ringkasan eksekutif, sejarah perusahaan, analisis pesaing, ringkasan pemilik, rencana operasi, data keuangan, proposal pinjaman dan jadwal pelaksanaan

\section{METODE PENELITIAN}

Jenis penelitian yang digunakan adalah metode deskriptif. Dengan metode deskriptif akan diperoleh deskripsi, gambaran atau lukisan secara sistematis, faktual dan akurat mengenai upaya peningkatan produktifitas wirausaha mandiri menuju ekonomi berkeadilan sebagai bentuk adaptasi selama pandemic.

Populasi penelitian yang diambil adalah wirausaha muda baik yang sudah punya usaha tetap maupun wirausaha sebagai usaha sampingan. Teknik sampling yang digunakan adalah purposive sampling sebanyak 137 orang manajemen keuangan usaha atau bisnis yang dijalani. Berbagai bentuk skala usahanya, manajemen keuangan itu penting.

Menurut (Suryana, 2014), dalam memulai usaha dibutuhkan perencanaan usaha yang memuat unsur-unsur ringkasan eksekutif, sejarah perusahaan, analisis pesaing, ringkasan pemilik, rencana operasi, data keuangan, proposal pinjaman dan jadwal pelaksanaan.

Metode pengumpulan data pada penelitian ini berupa data primer dan data sekunder.

Metode pengumpulan data primer diperoleh melalui penyebaran kuisioner dan teknik wawancara. Penyebaran kuisioner dilakukan dengan cara membagi kuisioner via google form kepada para responden. Selanjutnya tanggapan dari responden akan dikumpulkan dan dilakukan analisis. Teknik Wawancara dilakukan untuk mendapatkan gambaran yang detail mengenai objek penelitian.

Metode pengumpulan data sekunder dengan cara studi literatur yang berkaitan dengan topik permasalahan.

Definisi operasional dari variabel penelitian ditunjukkan pada tabel 1 . 
Tabel 1. Operasionalisasi Variabel Penelitian

\begin{tabular}{|c|c|c|c|}
\hline Variabel & Indikator & Skala Pengukuran & $\begin{array}{l}\text { Model Skala } \\
\text { Pengukuran }\end{array}$ \\
\hline \multirow{13}{*}{$\begin{array}{l}\text { Karakteristik } \\
\text { Pengusaha }\end{array}$} & \multirow[t]{6}{*}{ Entrepreneurial mentality } & Interval & Skala Likert \\
\hline & & Interval & Skala Likert \\
\hline & & Interval & Skala Likert \\
\hline & & Interval & Skala Likert \\
\hline & & Interval & Skala Likert \\
\hline & & Interval & Skala Likert \\
\hline & \multirow[t]{7}{*}{ Administrative mentality } & Interval & Skala Likert \\
\hline & & Interval & Skala Likert \\
\hline & & Interval & Skala Likert \\
\hline & & Interval & Skala Likert \\
\hline & & Interval & Skala Likert \\
\hline & & Interval & Skala Likert \\
\hline & & Interval & Skala Likert \\
\hline \multirow[t]{5}{*}{ Strategi Pemasaran } & Survey pelanggan & Interval & Skala Likert \\
\hline & Penyusunan market plan & Interval & Skala Likert \\
\hline & Pemanfaatan media sosial & Interval & Skala Likert \\
\hline & Komunikasi dengan pelanggan & Interval & Skala Likert \\
\hline & sebagai sponsorship & Interval & Skala Likert \\
\hline \multirow[t]{8}{*}{ Performa Bisnis } & Karakteristik produk dan jasa & Interval & Skala Likert \\
\hline & Tingkat penjualan & Interval & Skala Likert \\
\hline & Tingkat keuntungan & Interval & Skala Likert \\
\hline & Kemampuan permodalan & Interval & Skala Likert \\
\hline & Turnover karyawan yang rendah & Interval & Skala Likert \\
\hline & Luasnya pangsa pasar & Interval & Skala Likert \\
\hline & & Interval & Skala Likert \\
\hline & & Interval & Skala Likert \\
\hline
\end{tabular}

Sumber: Penulis (2021)

Dari variabel-variabel diatas akan diketahui sejauh mana upaya peningkatan produktifitas wirausaha mandiri menuju ekonomi berkeadilan sebagai bentuk adaptasi selama pandemic.

\section{Teknik Analisis}

Teknik analisis data terdiri atas :

a) Pengukuran Data

Pengukuran data terdiri atas data kualitatif dan data kuantitatif. Pengukuran data kualitatif terhadap tiga (3) variabel penelitian menggunakan kuisioner berbentuk skala likert. Kuisioner terdiri dari 4 pilihan jawaban, yaitu sangat setuju (SS), setuju (S), tidak setuju (TS) dan sangat tidak setuju (STS). Pengukuran secara kuantitatif dengan membuat distribusi frekuensi tentang upaya peningkatan produktifitas wirausaha mandiri menuju ekonomi berkeadilan sebagai bentuk adaptasi selama pandemic

b) Uji Validitas Kuesioner

Uji validitas kuisioner bertujuan untuk mengukur valid tidaknya suatu kuesioner. Pengujian dilakukan terhadap jawaban responden terhadap item-item butir pertanyaan pada kuesioner. Pengujian dilakukan dengan menggunakan rumus korelasi $r$ product moment yang menghubungkan jawaban responden setiap item butir pertanyaan dengan skor yang diperoleh masing-masing. Setiap item butir pertanyaan yang memiliki $r \geq 0,3$ dianggap valid (Sugiyono, 2017).

a) Uji Reliabilitas Kuesioner

Reliabilitas kuisioner bertujuan untuk menunjukkan konsistensi (reliable) dari alat ukur yang mengukur gejala yang sama di lain kesempatan. Pengujian dilakukan dengan menggunakan rumus Alpha Cronbach. Jika nilai Alpha Cronbach antara 0.70 - 0.90 maka reliabilitas tinggi. Jika nilai Alpha Cronbach $0.50-0.70$ maka reliabilitas moderat. Jika nilai Alpha Cronbach $<0.50$ maka reliabilitas rendah.

d). Rancangan Evaluasi.

Rancangan evaluasi dilakukan . dengan mengetahui persentase upaya peningkatan produktifitas wirausaha mandiri menuju ekonomi berkeadilan sebagai bentuk adaptasi selama pandemic melalui perhitungan distribusi frekuensi yang dinyatakan dalam ukuran persentase (\%) terhadap 3 variabel mengenai (1) Karakteristik Pengusaha, (2) Strategi Pemasaran, (3) Performa Bisnis. Semakin tinggi angka persentase yang diperoleh, semakin bagus upaya peningkatan produktifitas wirausaha mandiri menuju ekonomi berkeadilan sebagai bentuk adaptasi selama pandemi. 


\section{HASIL DAN PEMBAHASAN \\ Deskripsi Responden}

Diskripsi reponden dapat memberikan informasi mengenai jenis kelamin dan pekerjaan responden yang menjadi target penelitian.

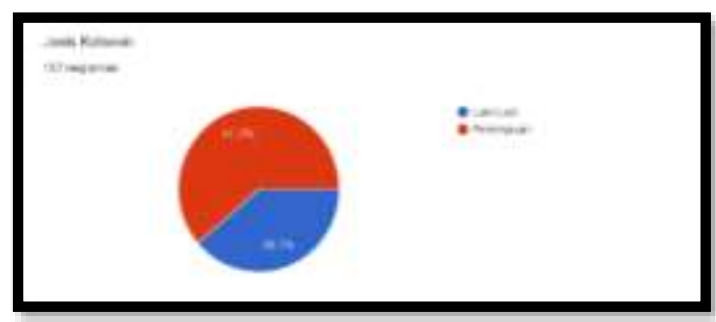

Gambar 4. Jenis Kelamin Responden ( Peneliti 2021)
Gambar 5. Pekerjaan Responden (Peneliti, 2021)

Pada gambar 4 menunjukkan, dari 137 responden terdiri atas $61,3 \%$ perempuan dan $38,7 \%$ laki-laki. Sebagian besar responden berprofesi sebagai mahasiswa $(87,6 \%)$, wiraswasta $(0,7 \%)$, pegawai swasta $(10,2 \%)$ dan pekerjaan lainnya (gambar 5). Hal ini menggambarkan target responden untuk menjadi wirausaha mandiri. Dari 137 responden, $12,4 \%$ diantara telah memiliki usaha dan $87,6 \%$ belum memiliki usaha.

\section{Uji Validitas Responden}

Hasil uji validitas responden ditunjukkan pada tabel 2.

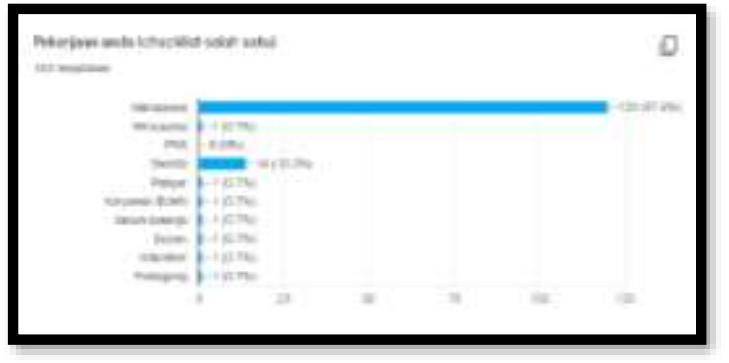

Tabel 2. Hasil Uji Validitas

\begin{tabular}{|c|c|c|c|c|}
\hline Variabel & Indikator & $\begin{array}{c}\text { Item } \\
\text { Pertanyaan }\end{array}$ & Hasil & Kesimpulan \\
\hline \multirow{13}{*}{$\begin{array}{l}\text { Karakteristik } \\
\text { Pengusaha }\end{array}$} & \multirow[t]{6}{*}{ Entrepreneurial mentality } & Item K1 & 0,350 & Valid \\
\hline & & Item K2 & 0,532 & Valid \\
\hline & & Item K3 & 0,606 & Valid \\
\hline & & Item K4 & 0,551 & Valid \\
\hline & & Item K5 & 0,413 & Valid \\
\hline & & Item K6 & 0,597 & Valid \\
\hline & \multirow[t]{7}{*}{ Administrative mentality } & Item K7 & 0,638 & Valid \\
\hline & & Item K8 & 0,552 & Valid \\
\hline & & Item K9 & 0,486 & Valid \\
\hline & & Item K10 & 0,544 & Valid \\
\hline & & Item K11 & 0,513 & Valid \\
\hline & & Item K12 & 0,457 & Valid \\
\hline & & Item K13 & 0,283 & Valid \\
\hline \multirow[t]{5}{*}{ Strategi Pemasaran } & Survey pelanggan & Item S1 & 0,732 & Valid \\
\hline & Penyusunan market plan & Item S2 & 0,746 & Valid \\
\hline & Pemanfaatan media sosial & Item S3 & 0,731 & Valid \\
\hline & $\begin{array}{l}\text { Komunikasi } \\
\text { pelanggan }\end{array}$ & Item S4 & 0,738 & Valid \\
\hline & sebagai sponsorship & Item S5 & 0,583 & Valid \\
\hline \multirow[t]{7}{*}{ Performa Bisnis } & Karakteristik produk dan jasa & Item P1 & 0,754 & Valid \\
\hline & Tingkat penjualan & Item P2 & 0,759 & Valid \\
\hline & Tingkat keuntungan & Item P3 & 0,677 & Valid \\
\hline & Kemampuan permodalan & Item P4 & 0,622 & Valid \\
\hline & $\begin{array}{l}\text { Turnover karyawan yang } \\
\text { rendah }\end{array}$ & Item P5 & 0,624 & Valid \\
\hline & Luasnya pangsa pasar & Item P6 & 0,739 & Valid \\
\hline & & Item P7 & 0,647 & Valid \\
\hline
\end{tabular}

Uji validitas kuisioner bertujuan untuk mengukur valid tidaknya suatu kuesioner. Pengujian dilakukan terhadap jawaban responden terhadap item-item butir pertanyaan pada kuesioner. Pengujian dilakukan dengan menggunakan rumus korelasi $r$ product moment yang menghubungkan jawaban responden setiap item butir pertanyaan dengan skor yang diperoleh masing-masing. Setiap item butir 
pertanyaan yang memiliki $\mathrm{r} \geq 0,3$ dianggap valid (Sugiyono, 2017).

Dari tabel 2, terlihat bahwa hasil uji validitas itemitem butir pertanyaan dari variabel karakteristik pengusaha, strategi pemasaran dan performa bisnis memiliki nilai $r \geq 0,3$ yang berarti valid.

\section{Uji Reliabilitas Responden}

Hasil uji reliabilitas responden ditunjukkan pada table 3.

Tabel 3. Hasil Uji Reliabilitas

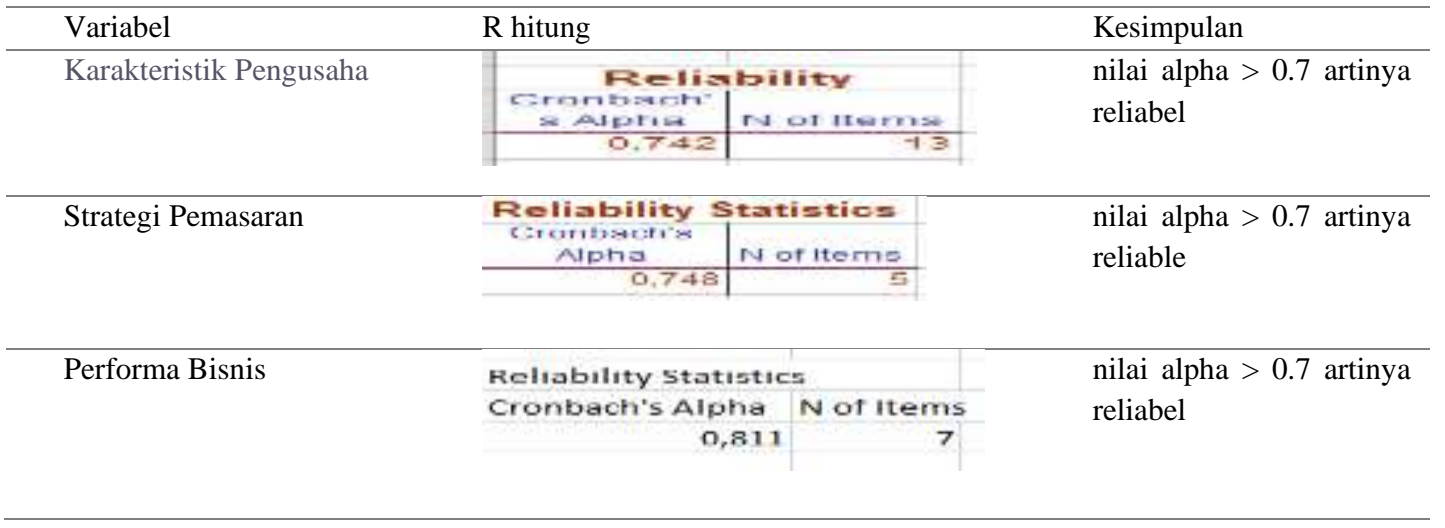

Reliabilitas kuisioner bertujuan untuk menunjukkan konsistensi (reliable) dari alat ukur yang mengukur gejala yang sama di lain kesempatan. Pengujian dilakukan dengan menggunakan rumus Alpha Cronbach. Jika nilai Alpha Cronbach antara $0.70-$ 0.90 maka reliabilitas tinggi. Jika nilai Alpha Cronbach 0.50 - 0.70 maka reliabilitas moderat. Jika nilai Alpha Cronbach $<0.50$ maka reliabilitas rendah. Dari tabel 3, terlihat bahwa hasil uji reliabilitas itemitem butir pertanyaan dari variabel karakteristik pengusaha, strategi pemasaran dan performa bisnis memiliki nilai alpha $>0.7$ artinya reliable.

\section{Karakteristik Pengusaha}

Proses operasi usaha akan dipengaruhi karakteristik wirausaha mandiri dalam menjalankan usahanya. Dua hal yang perlu dimiliki seorang wirausaha mandiri adalah entrepreneurial mentality dan administrative mentality. Entrepreneurial mentality adalah kemampuan mental seseorang wirausaha mandiri untuk bisa berinovasi menghasilkan produk-produk yang diinginkan konsumen, bisa memimpin team-work-nya dalam bekerja, bisa mengambil keputusan dalam memajukan usahanya, kemampuan melihat peluang usaha di masa yang akan datang, dan kemampuan problem solving. Seorang wirausaha mandiri dengan entrepreneurial mentality yang tinggi terlihat mandiri, individualistis, dan berpikir positif.

Gambar 6 menunjukkan hasil penelitian menunjukkan $81 \%$ responden bisa menemukan ide baru. Hal itu dilandasi $73 \%$ dari mereka punya kemauan untuk mengambail inisitif, 49,6\% menyatakan sebagai pengambil keputusan, sebanyak $79,6 \%$ bisa menyelesaikan masalah secara efektif dan efisien. Untuk menjadi wirausaha dibutuhkan pemikiran untuk maju ke depan. Mereka cenferung mengikuti trend yang ada sebanyak $57,7 \%$ dan $22,6 \%$ melanjutkan kegiatan usaha yang sudah ada. Seorang wirausaha mandiri dengan entrepreneurial mentality yang tinggi terlihat mandiri, individualistis, dan berpikir positif. Dengan adanya hasil diatas menunjukkan 137 responden sudah berupaya membentuk adaptasi baru selama pandemic dalam meningkatkan produktifitas dirinya yang tercermin dalam entrepreneurial mentality yang tinggi untuk menjadi wirausaha mandiri. 


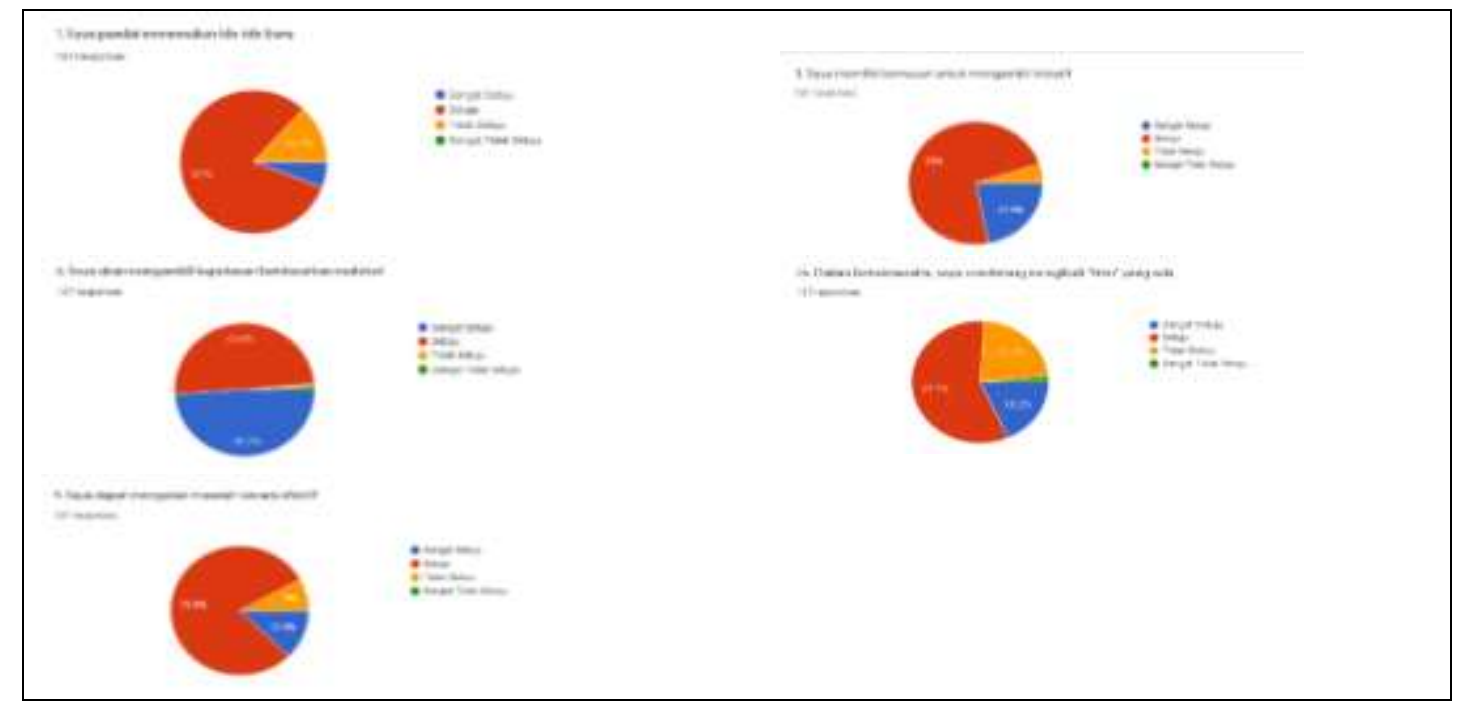

Gambar 6. Hasil Entrepreneurial mentality (Penulis, 2021)

Administrative mentality sendiri dibagi menjadi dua, yaitu analytical ability dan ability to the reality. Pada gambar 7 menunjukkan analytical ability seorang wirausaha harus mencari info yang detail tentang suatu permasalahan sebanyak $62 \%$ selanjutnya pencarian info yang detail tentang pemecahan masalah sebanyak $65 \%$. Prinsip yang runtut dan detail $66,4 \%$ perlu dimiliki seorang wirausaha. Analytical ability mencakup kemampuan seseorang untuk mengumpulkan informasi, berpikir sistematik, kalkulasi data, dan memecahkan masalah. Ability to the reality seorang wirausaha kemampuan tersebut harus diikuti dengan bisa kerjasama dengan orang lain sebesar $54 \%$ dan teguh dalam pendirian untuk mencapai tujuan yang realisitis. Ability to the reality mencakup kemampuan seseorang untuk bekerja sama, berpikir rasional, konsisten, dan stabil. Dengan adanya hasil diatas menunjukkan 137 responden sudah berupaya membentuk adaptasi baru selama pandemic dalam meningkatkan produktifitas dirinya yang tercermin dalam Administrative mentality yang tinggi untuk menjadi wirausaha mandiri.

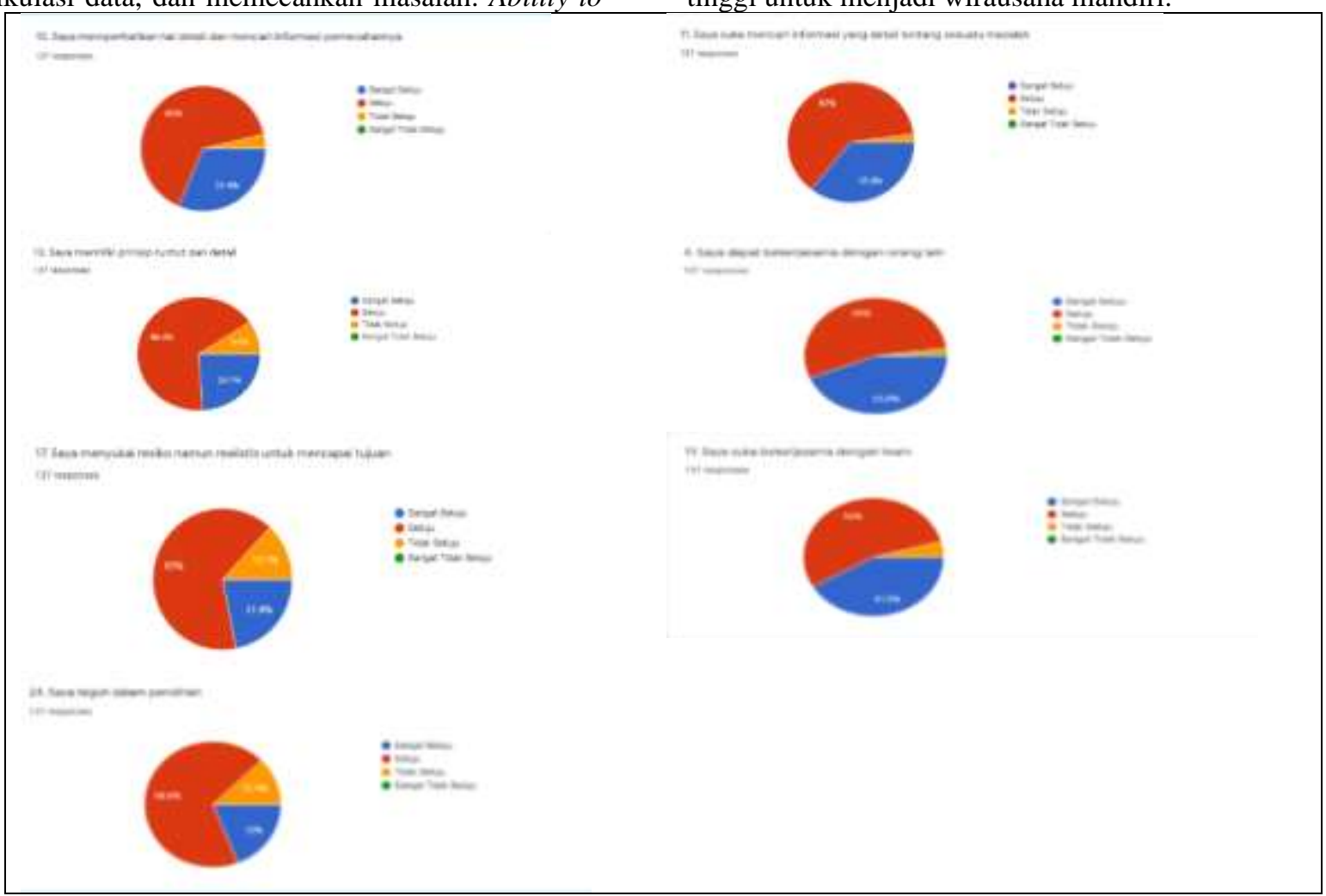

Gambar 7. Hasil Administrative mentality (Penulis 2021) 


\section{Strategi Pemasaran}

Prinsip dasar pemasaran adalah menciptakan nilai bagi pelanggan (customer value), keunggulan bersaing (competitif advantage) dan fokus pemasaran (Suryana, 2014). Strategi pemasaran adalah upaya untuk memasarkan produk yang dihasilkannya agar menjangkau pangsa pasar yang lebih luas. Strategi pemasaran yang dibikin disesuaikan dengan target pasar yang diinginkan. Oleh karena itu diperlukan kreatifitas dalam merancang strategi pemasaran yang tepat sasaran

Di samping itu, pandemic telah mengubah paradigma dalam berwirausaha. Wirausaha saat ini dituntut untuk melek teknologi untuk menunjang proses penjualannya yang mulai bergeser dari system offline ke system online. Dengan adanya system penjualan online, maka wirausah dituntut mahir menggunakan teknologi untuk memperluas pasar, memudahkan promosi dan update produk terbaru agar tidak tertinggal dengan pesaingnya.

Pada gambar 8 melakukan strategi pemasaran, dimulai survey pelanggan. Responden menyatakan $60,6 \%$ setuju adanya survey pelanggan. Hal ini untuk bisa memetakan apa saja yang dibutuhkan customer saat ini. Lalu diikuti penyusunan rencana pemasaran. Responden meyatakan $56,4 \%$ setuju diadakannya penyusunan rencana pemasaran. Hal ini perlu dilakukan agar bisa menjangkau target pasar yang lebih luas. Rencana pemasaran bisa melalui dari mulut ke mulut, via door to door, via sosial media dan lain sebagainya. Responden menyatakan $67,9 \%$ pemasaran dilakukan melalui sosial media. Karena untuk saat ini, pemasaran via medsos adalah yang paling ampuh untuk menjangkau pasar yang lebih luas. Hal yang tidak kalah penting adalah menjaga komunikasi dengan pelanggan. Hal ini dilakukan untuk menjaga loyalitas pelanggan atas produk-produk kita. Sebanyak $58,4 \%$ responden menyatakan sangat setuju atas usaha menjaga komunikasi dengan pelanggan. Untuk menjangkau pasar yang lebih luas, misal sampai mancanegara dengan cara menjadi sponsorship di salah satu acara. Sebanyak 73,7\% responden menyatakan setuju cara promosi seperti ini karena sebagai sponsorship suatu acara, nama toko ataupun nama produk akan mudah dilihat orang (jika tayang online, bisa ditanyangkan secara berulangulang) yang akan berdampak pada pesan yang mengena pada customer untuk diingat atas produk kita.

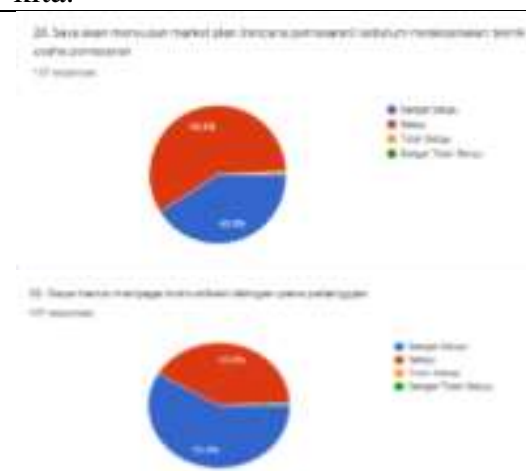

Gambar 8. Hasil Strategi pemasaran (Penulis 2021)

Dengan adanya hasil diatas menunjukkan 137 responden sudah berupaya membentuk adaptasi baru selama pandemic dalam meningkatkan produktifitas dirinya yang tercermin dalam penerapan strategi pemasaran yang bagus untuk menunjang menjadi wirausaha mandiri.

\section{Performa Bisnis}

Performa bisnis adalah gambaran yang menunjukkan perkembangan suatu usaha, berkembang naik atau turun. Usaha dengan performa baik ditunjukkan oleh tingkat penjualan yang tinggi, keuntungan dan pengembalian modal yang tinggi, turnover karyawan yang rendah, dan meluasnya pangsa pasar. Untuk memperoleh performa bisnis yang baik, perlu manajemen yang baik terutama manajemen keuangan usaha atau bisnis yang dijalani. 


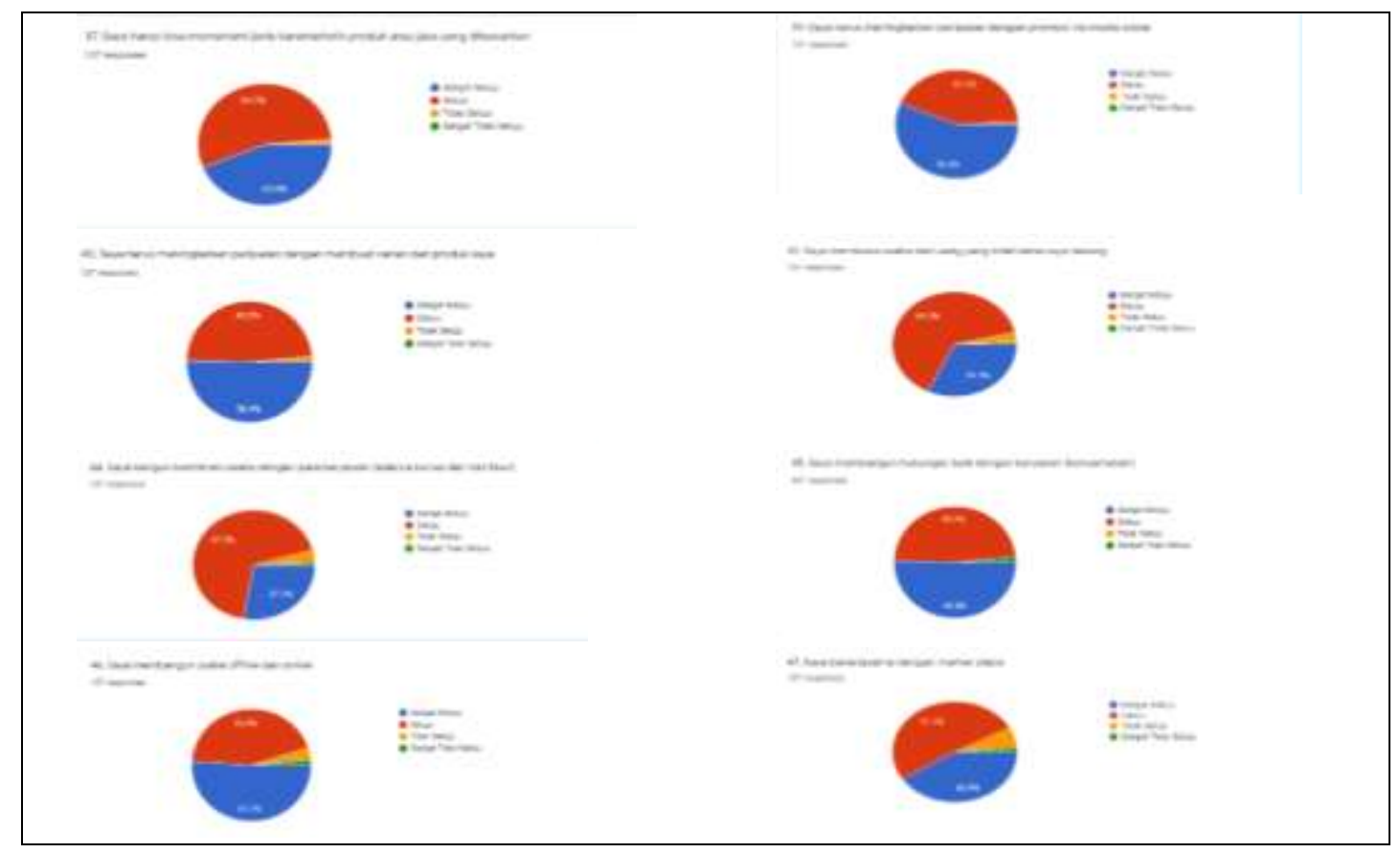

Gambar 9. Hasil Performa Bisnis (Penulis 2021)

Dengan adanya hasil diatas menunjukkan 137 responden sudah berupaya membentuk adaptasi baru selama pandemic dalam meningkatkan produktifitas dirinya yang tercermin dalam penerapan performa bisnis yang bagus. Hal ini ditunjukkan pada gambar 9 sebanyak 54,7\% responden memahami karakteristik produk yang mereka jual, 56,2\% responden memasarkan produknya melalui media sosial. Untuk memperluas pasarnya $50,4 \%$ responden melakukan launching variasi produk yang sudah ada. Sebanyak $64, \%$ reponden menyatakan modal diperoleh dari tabungan yang selama ini disimpan. Mereka tidak mengambil pinjaman modal dari bank karena adanya bunga bank yang tinggi. Untuk menjaga hubungan dengan karyawan sebanyak $67,9 \%$ responden setuju memberikan bonus ataupun liburan. Hal ini untuk menjaga komitmen karyawan pada perusahaannya karena 51,1\% menyatakan usahanya terdiri dari usaha online dan offline. Dengan 2 bentuk toko ini, responden mengharapkan untung yang besar. Jadi customer bisa melakukan transaksi via toko online maupun transaksi via toko offline. Untuk memperluas pangsa pasarnya secara online dan menjaga kepercayaan konsumen sebanyak $51,1 \%$ responden bergabung dengan market place. Dengan bergabung ke market place akan mendatangkan keuntungan, yaitu prosedur administrasi yang mudah dan praktis, penjual tidak perlu menyewa tempat untuk membuka lapak jualan karena sudah tersedia di market place, menciptakan peluang membangun relasi yang lebih luas dengan penjual lain melalui komunitas. Dengan tergabung dalam komunitas, para penjual dapat saling berbagi ilmu, berbagi peluang, berbagi info-info penting dan bekerjasama dalam membangun peluang baru.

\section{IMPLEMENTASI MANAJERIAL}

Implementasi manajerial untuk hasil penelitian ini adalah bahwa dengan adanya upaya peningkatan produktifitas wirausaha melalui perbaikan karakteristik pengusaha yang unggul, perbaikan strategi pemasaran dan peningkatan performa bisnis merupakan bentuk adaptasi baru dimasa pandemi agar terwujud wirausaha mandiri menuju ekonomi berkeadilan. Di samping itu, pandemic telah mengubah paradigma dalam berwirausaha. Wirausaha saat ini dituntut untuk melek teknologi untuk menunjang proses penjualannya yang mulai bergeser dari system offline ke system online. Dengan adanya system penjualan online, maka wirausah dituntut mahir menggunakan teknologi untuk memperluas pasar, memudahkan promosi dan update produk terbaru agar tidak tertinggal dengan pesaingnya. Hal ini memberikan motivasi untuk bertahan ditengah persaingan yang tinggi dengan penguasaaan TIK yang mumpuni dan melakukan ekspansi ke mancanegara.

\section{IMPLEMENTASI TEORITIS}

Implementasi teoritis untuk hasil penelitian ini adalah agar terwujud wirausaha mandiri menuju ekonomi berkeadilan, maka penerapan strategi bersaing berupa Strategi Kepemimpinan Biaya (Cost Leadership Strategy), Strategi Diferensiasi (Differentiation Strategy), Strategi Inovasi (Innovation Strategy), Strategi Pertumbuhan (Growth Strategy), Strategi Aliansi (Alliance Strategy). 


\section{KESIMPULAN}

Kesimpulan penelitian ini menunjukkan bahwa upaya peningkatan produktifitas wirausaha melalui perbaikan karakteristik pengusaha yang unggul, perbaikan strategi pemasaran dan peningkatan performa bisnis merupakan bentuk adaptasi baru dimasa pandemi agar terwujud wirausaha mandiri menuju ekonomi berkeadilan. Hasil penelitian ini juga memiliki dua implementasi:

Implementasi teoritis untuk hasil penelitian ini adalah agar terwujud wirausaha mandiri menuju ekonomi berkeadilan, maka penerapan strategi bersaing berupa Strategi Kepemimpinan Biaya (Cost Leadership Strategy), Strategi Diferensiasi (Differentiation Strategy), Strategi Inovasi (Innovation Strategy), Strategi Pertumbuhan (Growth Strategy), Strategi Aliansi (Alliance Strategy) Implementasi manajerial untuk hasil penelitian ini adalah bahwa dengan adanya upaya peningkatan produktifitas wirausaha melalui perbaikan karakteristik pengusaha yang unggul, perbaikan strategi pemasaran dan peningkatan performa bisnis merupakan bentuk adaptasi baru dimasa pandemi agar terwujud wirausaha mandiri menuju ekonomi berkeadilan. Di samping itu, pandemic telah mengubah paradigma dalam berwirausaha. Wirausaha saat ini dituntut untuk melek teknologi untuk menunjang proses penjualannya yang mulai bergeser dari system offline ke system online. Dengan adanya system penjualan online, maka wirausah dituntut mahir menggunakan teknologi untuk memperluas pasar, memudahkan promosi dan update produk terbaru agar tidak tertinggal dengan pesaingnya. Hal ini memberikan motivasi untuk bertahan ditengah persaingan yang tinggi dengan penguasaaan TIK yang mumpuni dan melakukan ekspansi ke mancanegara.

\section{REFERENSI}

Agustina, L. (2019). Riset Desain Penelitian Indeks Pengelolaan Informasi Dan Komunikasi. https://balitbangsdm.kominfo.go.id/satker/paik p/berita-seminar-riset-desain-penelitianindeks-pengelolaan-informasi-dankomunikasi-5-7

Bayu, D. . (2020). 6 Sektor Usaha Paling Terdampak Saat Pandemi-Corona. https://databoks.katadata.co.id/datapublish/202 0/09/15/6-sektor-usaha-paling-terdampak-saatpandemi-corona

Heizer, Jay dan Render, B. (2015). Manajemen Operasi: Keberlangsungan Rantai Pasokan. (11th ed.). International Review of Management and Marketing.

Jayani, D. (2020). Penurunan Penjualan UmkmImbas Pandemi covid-19. https://databoks.katadata.co.id/datapublish/202 0/06/10/penurunan-penjualan-umkm-imbaspandemi-covid-19

Rosita, R. (2020). Pengaruh Pandemi Covid-19 Terhadap UMKM Di Indonesia. Lentera Bisnis, 9, 109-120.

Sugiyono. (2017). Metode Penelitian Kuantitatif Kualitatif dan $R \& D$ (25th ed.). Alfabeta.

Supranto, J. (2019). Perilaku Konsumen Dan Strategi Pemasaran (2nd ed.). Mitrawacanamedia.

Suryana. (2014). Kewirausahaan Kiat dan Proses Menuju Sukses. Salemba Empat. 